\title{
Factors Causing Contraceptive Acceptors Drop Out
}

\author{
Faktor-faktor Penyebab Akseptor Kontrasepsi Drop Out
}

\author{
Mufdlilah*, Kanthi Aryekti**
}

\begin{abstract}
*Master of Midwifery Program, Faculty of Health Sciences, 'Aisyiyah University of Yogyakarta, Yogyakarta, Indonesia, **National Population and Family Planning Board Representative of Special Region of Yogyakarta Province, Yogyakarta, Indonesia
\end{abstract}

\begin{abstract}
Family planning programs have strategic, comprehensive, and fundamental meaning in actualizing healthy and prosperous Indonesians. The high incidence of drop-out contraceptive acceptors needs an effort to make the acceptors continuously using contraceptives. This study aimed to determine factors causing acceptors drop out. This study was an analytical survey with cross-sectional approach. The study was conducted on July to December 2016 . The study population was contraceptive acceptors who dropped out within 3 consecutive months and were not getting pregnant with a sample size of 52 people. Data was collected by open and closed questionnaire. The survey results revealed age $(\mathrm{OR}=6.486 ; 95 \% \mathrm{Cl}=1.500-28.041)$, education $(\mathrm{OR}=1.129 ; 95 \% \mathrm{Cl}=0.265$ -4.804 ), contraceptive records ( $\mathrm{OR}=5.845 ; 95 \% \mathrm{Cl}=1.252-27.287)$, and side effects ( $\mathrm{OR}=5.983 ; 95 \% \mathrm{Cl}=1.150-31.136)$. In conclusion, contraceptive records, side effects, cost, and age significantly affect the acceptors drop out, while education does not affect acceptors drop out.
\end{abstract}

Keywords: Drop-out acceptors, side effects, contraceptive

\section{Abstrak}

Program keluarga berencana (KB) memiliki makna yang sangat strategis, komprehensif dan fundamental dalam mewujudkan orang Indonesia yang sehat dan sejahtera. Tingginya angka kejadian akseptor KB drop out memerlukan suatu upaya agar akseptor KB tetap menggunakan alat kontrasepsi. Penelitian ini bertujuan untuk mengetahui faktor-faktor penyebab akseptor drop out. Penelitian ini merupakan survei analitik dengan pendekatan potong lintang. Penelitian dilakukan pada bulan Juli sampai Desember 2016. Populasi penelitian yaitu akseptor KB yang drop out selama 3 bulan berturut-turut dan tidak sedang hamil dengan jumlah sampel 52 orang. Pengumpulan data dilakukan dengan kuesioner tertutup dan terbuka. Berdasarkan hasil penelitian, diketahui usia $(\mathrm{OR}=6,486 ; 95 \% \mathrm{Cl}=1,500-28,041)$, pendidikan $(\mathrm{OR}=1,129 ; 95 \% \mathrm{Cl}=0,265-4,804)$, riwayat $\mathrm{KB}(\mathrm{OR}=5,845 ; 95 \% \mathrm{Cl}=1,252-27,287)$, dan efek samping $(O R=5,983 ; 95 \%=1,150-31,136)$. Sebagai kesimpulan, usia, pendidikan, dan efek samping berpengaruh signifikan penyebab akseptor KB drop out, sedangkan pendidikan tidak berpengaruh terhadap akseptor KB drop out.

Kata kunci: Akseptor drop out, efek samping, kontrasepsi

How to Cite: Mufdlilah, Aryekti K. Factors causing contraceptive acceptors drop out. Kesmas: National Public Health Journal. 2018; 12(4): 202-206. (doi:10.21109/kesmas.v12i4.1509)
Correspondence: Mufdlilah, Faculty of Health Sciences 'Aisyiah University of Yogyakarta, West Ring Road Nogotirto, Gamping, Sleman, Yogyakarta, Phone: +62274-4469204,E-mail: mufdlilah.stikes@gmail.com

Received: May $29^{\text {th }} 2017$

Revised: January $17^{\text {th }} 2018$

Accepted: April $30^{\text {th }} 2018$ 


\section{Introduction}

According to family planning worldwide in Buletin Jendela Data dan Informasi Kesehatan, Indonesia has 65 million reproductive women. The number is the highest compared to other Southeast Asian countries, such as Vietnam with 25.3 million, the Philippines with 23 million, Thailand with 17.9 million, Myanmar with 14.1 million, Cambodia with 4 million, Lao with 1.6 million, and Timor Leste with 0.3 million. Based on 2012 data of the National Population and Family Planning Board (BKKBN) of Special Region of Yogyakarta, the number of couples at reproductive age equals to 47,692 people consisting of 1,780 new contraceptive participants and 36,267 active contraceptive participants. ${ }^{1,2}$

Based on data from the World Health Statistics, the rate of contraceptive acceptors in Southeast Asian countries in 2005-2012, including Thailand at $80 \%$, Cambodia at $79 \%$, Vietnam at $78 \%$, Indonesia at $61 \%$, the Philippines at $49 \%$, Lao at $38 \%$, and Timor Leste at $22 \%$ to the percentage of the average use of contraceptives amounted to $58.1 \%$ means that Indonesia exceeds the average for contraceptive use. However, the total fertility rate (TFR) of Indonesia (2.9\%) is under the average TFR of other Southeast Asian countries, namely Timor Leste at $6.6 \%$, the Philippines at $3.5 \%$, Cambodia at $3.4 \%$, Lao at $3.3 \%$, Malaysia at $2.6 \%$, Brunei Darussalam at $2.3 \%$, Vietnam at $1.9 \%$, Thailand at $1.6 \%$, Singapore at $1.3 \% .3,1$ The percentage of contraceptive acceptors in the Special Region of Yogyakarta in 2013 showed 46.84\% injection acceptors, $25.13 \%$ pill acceptors, $11.53 \%$ IUD acceptors, $9.17 \%$ implant acceptors, 3.48\% tubectomy acceptors, $0.3 \%$ vasectomy acceptors and $3.13 \%$ condom acceptors. Meanwhile, there were only 1,356 new contraceptive participants consisting of 771 IUD acceptors (56.86\%), 60 tubectomy acceptors $(4.42 \%), 3$ vasectomy acceptors $(0.22), 60$ condom acceptors $(4.42 \%), 87$ implant acceptors $(6.42 \%), 345$ injection acceptors (25.44\%), and 30 pill acceptors $(2.21 \%) .4$

There are two methods of contraception, namely the selection of long-term contraception method (LTCM) and Non-LTCM. Non-LTCM usage is greater than LTCM as LTCM usage ratio in 2012 is 10.6 LTCM and NonLTCM at 47.3 with 45 usage ratio. Opportunities of greater drop-out acceptors occur in Non-LTCM by 20$40 \%$ because these contraceptives last only 1-3 months. Moreover, the drop-out can be caused by several, reasons such as weight gain, weight loss, bleeding, hypertension, dizziness, nausea, not menstruation, weakness, etc. ${ }^{5,6}$

The rate of drop-out acceptors in Yogyakarta in 2013 was quite high at around $16-20 \%$ compared to last year at below $10 \%$. The reason of drop-out acceptors expecting to get pregnant was as much as $5 \%$, problems in selected contraception methods at $5 \%$, while other reasons (cost, discomfort, divorce, infrequent sexual intercourse) at $3 \%$, failure to use contraception at $2 \%$, and desire to change the methods of contraception at $13 \% .7,8$ The results of the analysis conducted by the National Population and Family Planning Board of the Special Region of Yogyakarta show that 16 contraceptive participants in the region only raise 1 active contraceptive participant, which means that many new participants switch to another contraceptive. Therefore, assessment on the incidence and causes of drop-out needs to be carried out. The aim of this study was to determine factors causing the acceptors drop out.

\section{Method}

This study had been through ethical approval No.01/KEP-SAY-VII-2015. The study was analytical survey study with cross-sectional approach. Population of study was all contraceptive acceptors consecutively being stopped or they stopped using contraceptives. The sample was 52 acceptors with criteria that were consecutively stopped using contraceptives within 3 months, LTCM or Non-LTCM, and not getting pregnant at the time when data were taken. Data collection used questionnaire. This study took place in the Special Region of Yogyakarta in cooperation with the National Population and Family Planning Board of Gunung Kidul and Bantul District. Statistical analysis was conducted using chi-square $\left(\chi^{2}\right)$.

\section{Results}

This study was conducted on 52 drop-out contraceptive acceptors through open and closed questionnaire data assisted by voice recorder during interview. Characteristics of respondents include age, education level, occupation, contraceptive records, and side effects. Table 1 shows that the age of most mothers who drop out was $>35$ years $(53.8 \%)$, most respondents attained higher education $(36.5 \%)$, respondents were unemployed or housewives $(46.2 \%)$, respondents ever used contraceptives (26.9\%), and in average mothers drop out because of obesity side effect $(26.9 \%)$.

Results of bivariate analysis found a significant relation between age, contraceptive records, and side effects with the incidence of drop out $(\mathrm{p}$ value $=0.05)$ (Table 2 ). Table 3 presents the results of multivariate analysis showing maternal age $(\mathrm{OR}=6.486 ; 95 \% \mathrm{CI}=1.500$ $28.041)$ education level $(\mathrm{OR}=1.129 ; 95 \% \mathrm{CI}=0.265$ $4.804)$, contraceptive records $(\mathrm{OR}=5.845 ; 95 \% \mathrm{CI}=$ 1.252 - 27.287) and side effects $(\mathrm{OR}=5.983 ; 95 \% \mathrm{CI}$ 1.150 - 31.136). There were three variables causing acceptors drop out that were maternal age, contraceptive records, and side effects, while knowledge did not influence acceptors to drop out.

\section{Discussion}

Based on results of analysis, there were several rea- 
Table 1. Descriptive Statistics

\begin{tabular}{|c|c|c|c|c|c|}
\hline Variables & Category & Mean & $95 \%$ CI & Min & Max \\
\hline Institutional delivery & & 0.72 & $0.71-0.73$ & 0 & 1 \\
\hline Health insurance & & 0.45 & $0.44-0.46$ & 0 & 1 \\
\hline Age (years) & & 28.26 & $28.17-28.35$ & 13 & 49 \\
\hline \multirow[t]{3}{*}{ Parity } & 3 children & 0.32 & $0.31-0.33$ & 0 & 1 \\
\hline & 2 children & 0.35 & $0.34-0.36$ & 0 & 1 \\
\hline & 1 child & 0.33 & $0.32-0.34$ & 0 & 1 \\
\hline \multirow[t]{3}{*}{ Education } & Elementary school & 0.36 & $0.36-0.37$ & 0 & 1 \\
\hline & Junior high school & 0.27 & $0.26-0.27$ & 0 & 1 \\
\hline & High school & 0.37 & $0.36-0.38$ & 0 & 1 \\
\hline \multirow{5}{*}{ Economic status } & Lowest & 0.13 & $0.12-0.14$ & 0 & 1 \\
\hline & Low-middle & 0.18 & $0.18-0.19$ & 0 & 1 \\
\hline & Middle & 0.23 & $0.22-0.24$ & 0 & 1 \\
\hline & Upper-middle & 0.27 & $0.26-0.27$ & 0 & 1 \\
\hline & Highest & 0.19 & $0.19-0.20$ & 0 & 1 \\
\hline One-way travel time to health facility $<60$ minutes & & 0.93 & $0.92-0.93$ & 0 & 1 \\
\hline One-way travel cost to health facility < USD 1 & & 0.84 & $0.83-0.84$ & 0 & 1 \\
\hline Living in urban area & & 0.52 & $0.50-0.53$ & 0 & 1 \\
\hline Living in Java-Bali & & 0.59 & $0.57-0.60$ & 0 & 1 \\
\hline Health facility ratio & & 5.49 & $5.41-5.57$ & 0.93 & 21.25 \\
\hline Health professional ratio & & 3.23 & $3.18-3.29$ & 0.24 & 18.77 \\
\hline Long distance to health facility $(\mathrm{km})$ & & 3.12 & $3.11-3.13$ & 1.81 & 7.42 \\
\hline Intended pregnancy & & 0.85 & $0.84-0.86$ & 0 & 1 \\
\hline Complete antenatal care visit & & 0.73 & $0.72-0.74$ & 0 & 1 \\
\hline Pregnancy complication & & 0.14 & $0.13-0.14$ & 0 & 1 \\
\hline Childbirth complication & & 0.13 & $0.12-0.13$ & 0 & 1 \\
\hline
\end{tabular}

Note: $\mathrm{CI}=$ Confidence Interval

Table 2. Bivariate Analysis

\begin{tabular}{lcrc}
\hline Variable & Correlation Coef & OR & p Value \\
\hline Age & 0.50 & 10.22 & $0.001^{*}$ \\
Education level & 0.12 & 0.16 & 0.413 \\
Contraceptive records & 0.34 & 4.22 & $0.025^{*}$ \\
Side effects & 0.36 & 5.00 & $0.011^{*}$ \\
\hline
\end{tabular}

Note:

OR= Odds Ratio

Table 3. Multivariate Analysis

\begin{tabular}{lcrrr}
\hline Variable & $\boldsymbol{\beta}$ & $\mathbf{p ~ V a l u e}$ & OR & \multicolumn{1}{c}{$\mathbf{9 5 \%}$ CI } \\
\hline Age & 1.87 & $0.012^{*}$ & 6.49 & $1.50-28.04$ \\
Education level & 0.12 & 0.869 & 1.13 & $0.27-4.80$ \\
Contraceptive records & 1.77 & $0.025^{*}$ & 5.85 & $1.25-27.29$ \\
Side effects & 1.79 & $0.034^{*}$ & 5.98 & $1.15-31.14$ \\
\hline
\end{tabular}

Notes:

*significant $\mathrm{p}$ Value $<0.05 ; \mathrm{OR}=$ Odds Ratio; $\mathrm{CI}=$ Confidence Interval

sons of contraceptive acceptors drop out, which included age, contraceptive records, side effects. However, education level did not significantly influence acceptors to drop out. In this study, respondents were mostly at the age of greater than 35 years. This age belongs to high risk for mothers, especially if mothers expect to have more children, so the use of contraceptives is recommended as a way of preventing pregnancy, and this can help improve health level. Therefore, selection of contraceptives which would be used should be right, so this can minimalize in- compatibility of using contraceptives that may lead acceptors to drop out. This is in line with previous study by Mufdlilah \& Kanthi, ${ }^{9}$ that the age of greater than 35 years is at higher risk of drop out. Moreover, this study is also supported by Tolley, et al., 10 that the age is influential to the occurrence of drop-out acceptors, especially contraceptive implant users.

Another factor found in this study was contraceptive records influential to the occurrence of drop-out acceptors because of many reasons, including setting pregnancy and not expecting childbirth again. However, in human's life, couple in family expect more than one child, so this becomes the reason by contraceptive acceptors to drop out, not fit to use contraceptives, acceptor wants to change contraceptive method, rumors, and culture understood. Thus, acceptors with good records of contraceptives sometimes drop out or make different decisions, so they do not use contraceptives.

Contraceptive records found in this study indicated that almost all respondents had ever used contraceptives. The condition depicts that in the location of study, the people still paid attention to welfare and health of their families by using contraceptives, so as they care of their family's future. Respondents who had ever dropped out then still want to take contraception, the higher public awareness to use contraceptives again because the use of contraceptives is an important way to control the number of children or birth. By birth control in family, it creates 
a prosperous family, both in terms of their economy, education, and health. This study is supported by $\mathrm{N}$. Peyman and Oakley, ${ }^{11}$ stating that contraceptive records may cause drop out due to less support, special treatment, handling, side effects, cultural approach, clinical efforts, and the low self-confidence of acceptos.

The contraceptive type mostly used by acceptors was contraceptive injection because injection did not make direct risks, acceptors felt comfort with services, also practical and affordable. However, not all people have known the effect of prolonged use of hormonal contraceptives. This long-term use of contraceptive is a contraceptive method mostly selected by women of childbearing age compared to Non-LTCM. The use of this contraceptive method needs strong support and motivation, both from the acceptors themselves and their husbands because it causes complaints or side effects in acceptors. Therefore, it needs communication, information, and education on selection of hormonal contraceptives that is good and fit with age, when to stop, and always remind to reschedule visits so as the use of contraceptives is not stopped or drop out. ${ }^{12}$

Another factor causing contraceptive acceptors to drop out was side effects. Side effect is reaction that may be resulted after the use of medicine or tool. The side effect can be mild or severe. It is mild if it still could be overcome, the use of contraceptives would be continued. Otherwise, if reactions could not be overcome and so disturbing, most of acceptors would remove or do not continue the use of contraceptives. In this study, side effects affected were uncomfortable feeling, headache, and menstrual disorder, so the acceptors decided not to continue the use of contraceptives. The menstrual disorder is one of side effects among contraceptive acceptors, so the use of contraceptives is stopped as it can affect the health of urban people. ${ }^{12}$ Menstrual disorders and weight gain are side effects of contraceptive use, The results of this study are similar to that of Sabatini, et al, ${ }^{13}$ that menstrual disorders and weight gain are the side effects of contraceptive use.

This study was supported by American Physician that side effects of contraceptives are weight gain, headache, pain in the breast, irregular menstruation, mood changes, low libido, acne, and nausea. ${ }^{14}$ This is also in line with study by Whetsoff, 15 that many contraceptive oral acceptors drop out because it causes headache, weight gain, and three-month spotting. This study is supported by Musdalifah's opinion that acceptors drop out because of uncomfortable and insecure feelings, less support from husband, so they choose to stop using contraceptives. The husband's role to support mother drop out due to side effect complaints is very important because husband is a person who always wants his partner healthy. The role of position of husband is the determinant in making family decision, so the wife must obey and respect the decision of the husband. 16

Khan, ${ }^{17}$ also thought that the occurrence of contraceptive acceptors who drop out due to side effects is caused by lack of counseling. Study by Tolley, ${ }^{10}$ found that $30 \%$ of contraceptive acceptors did not use contraceptives due to side effects by 1.4 times because of less support from husband and management support related to contraception, and due to side effects resulted such as bleeding within the first six months and six-day spotting in the use of contraceptive injection at $70 \%$, IUD at $34 \%$, and implant at $10 \%$, so this caused contraceptive acceptors drop out at 2-4\%. In addition, reasons of stop using contraceptives were failure records due to pregnancy, less awareness, and side effects. ${ }^{18}$

The results of this study indicate that there is no effect between education and contraceptive causes because the knowledge of each person is different. This can be influenced by rumors, culture, environment, and other support including health workers. The latest education of most respondents in the location of study was higher education. The low or the high education level is not enough to move people's mindset to participate. This is in line with study by Littlejhon, ${ }^{19}$ stating that there is no racial, educational difference that affects the use of contraceptive injection. The result of this study is different from the study by Follan, ${ }^{20}$ that education affects on the incidence of drop-out contraceptive acceptors. In this study, acceptors' acceptance of contraceptive services through informed consent and contraceptive systems are understood by acceptors including side effects that occur in each acceptor. This is strongly supported by human resources in providing services especially the officers' skill, adaptation of contraceptives received by the acceptors' body system, and acceptors' experiences on side effects of contraceptive use.

\section{Conclusion}

Education is not influential to cause the acceptors drop out, but contraceptive records, side effects, and age influence acceptors to drop out.

\section{Recommendation}

Efforts to provide health promotion on contraceptives should be developed, so the acceptors can get clearer information. Moreover, maintaining public awareness not to stop using contraceptives is recommended to help improve public health level.

\section{Acknowledgment}

Researchers would like to thank the National Population and Family Planning Board of The Special Region of Yogyakarta that has facilitated, both in forms of funds and facilities in this study. 


\section{References}

1. Pusat Data dan Informasi Kementerian Kesehatan Republik Indonesia. Situasi keluarga berencana di Indonesia. Buletin Jendela Data dan Informasi Kesehatan. 2013; 2 (2): 1-44.

2. Badan Pusat Statistik Daerah Istimewa Yogyakarta. Daerah Istimewa Yogyakarta in Figure. Yogyakarta: Badan Pusat Statistik Daerah Istimewa Yogyakarta; 2011.

3. World Health Organization. World health statistics 2013. Geneva World Health Organization; 2013. 172 p.

4. Badan Kependudukan dan Keluarga Berencana Nasional. Evaluasi pelaksanaan program populasi dan keluarga berencana pada tahun 2012. Jakarta: Badan Kependudukan dan Keluarga Berencana Nasional; 2013.

5. Statistik Indonesia, Badan Kependudukan dan Keluarga Berencana Nasional, dan Departemen Kesehatan, dan ICF Internasional. Survei demografi dan kesehatan Indonesia 2012. Jakarta: Statistik Indonesia, Badan Kependudukan dan Keluarga Berencana Nasional, dan Departemen Kesehatan, dan ICF Internasional; 2013.

6. Statistik Indonesia dan Makro Internasional. Survei demografidan kesehatan Indonesia 2007. Calverton, Maryland, USA: BPS and Makro Internasional; 2008.

7. Badan Pusat Statistik, Badan Kependudukan dan Keluarga Berencana Nasional, Kementerian Kesehatan dan ICF Internasional. Laporan pendahuluan survey demografi kesehatan Indonesia. Jakarta: Badan Pusat Statistik, Badan Kependudukan dan Keluarga Berencana Nasional, Kementerian Kesehatan dan ICF Internasional; 2012.

8. Badan Kependudukan dan Keluarga Berencana Nasional. Rakernas development of population and family planning in 2012. Jakarta: Badan Kependudukan dan Keluarga Berencana Nasional; 2013.

9. Mufdlilah and Kanthi A. Dukungan suami terhadap drop out bagi akseptor keluarga berencana (KB) di desa dan kota Daerah Istimewa Yogyakarya. Musawa: Jurnal Studi Gender dan Islam. 2016; 15(1): 103-
13.

10. Tolley E, Loza S, Kafafi L, Cummings S. The impact of menstrual side effect on contraceptive discontinuation: finding from a longitudinal study in Cairo, Egypt. International family perspectives. 2005; 31(1): $15-23$

11. Peyman N, Oakley D. Effective contraceptive use: an exploration of theory-based influences. Health Education Research. 2009; 24(4). 575-85

12. Rahardja MB. Kualitas Pelayanan keluarga berencana dan pengantian kontrasepsi di Indonesia. Kesmas: Jurnal Kesehatan Masyarakat Nasional. 2011; 6(3): 140-4.

13. Sabatini R, Cagiano R, Rabe T. Adverse effects of hormonal contraception. Journal of Reproductive Medicine and Endocrinology. 2011; 8 (1): 130-56.

14. Your Family Doctor. Side effect of hormonal contraceptives. American Family Physician. 2010; 82(12): 1509.

15. Westhoff CL, Heartwell S, Edwards S, Zieman M, Stuart G, Cwiak C, et al. Oral contraceptive discontinuation: do side effects matter? American Journal of Obstetrics \& Gynecology. 2007;196(4): 412.e1412.e7.

16. Musdalifah, Hanis. Factors associated with drop out on kb acceptors in district Labakkang. Journal of Stikes Nani Hasanuddin. 2013; 3(4): 111.

17. Khan MA. Side effect and oral contraceptive discontinuation in Ruralbangladesh, Contraception. 2001; 64(3). 161-7.

18. Indrawati L. Determinan kejadian berhenti pakai (drop out), Buletin Penelitian Sistem Kesehatan. 2014; 17 (1). 55-62.

19. Littlejhon KE. Hormonal contraceptive use and discontinuation because of dissatisfaction: differences by race and education, demography. 2012; 49(4): 1433-52.

20. O-Fallon JB, Ilene SS, Javier C, Franscisco R. An analysis of contraceptive discontinuation among female. Reversible Method User in Urban Honduras. 2011; 12(1): 11-20. 